Brit. F. vener. Dis. (1969), 45, 144.

\title{
GONORRHOEA TREATED BY A COMBINATION OF PROBENECID AND SODIUM PENICILLIN G*
}

\author{
BY \\ G. A. OLSEN AND G. LOMHOLT \\ Gonococcus Laboratory, fulianehaab, Greenland \\ Auken and Lomholt Dermato-venerology Clinic, Copenhagen, Denmark
}

In an area with a high incidence of gonorrhoea, where strains of Neisseria gonorrhoeae having a reduced sensitivity to penicillin in vitro are common, there is an urgent need for effective routine therapy. Furthermore, when local conditions are such that diagnosis and therapy are in the hands of personnel with a limited training, treatment must be both simple and easy to administer. When the form of treatment to be described was introduced into Greenland in 1964 (Lomholt and Berg, 1966), it had to fulfil these requirements. The incidence of gonorrhoea was greater than 100 cases per 1,000 population. The treatment previously used had failed in 27 per cent. (Bøggild, 1965), and 86 per cent. of the strains of Neisseria gonorrhoeae tested had shown a reduced sensitivity to penicillin in vitro.

The daily management of gonorrhoea among the two-fifths of the population living outside the towns, or rather villages, was mostly in the hands of midwives with limited medical training.

The reasion for combining the quick-acting sodium penicillin $G$ with probenecid is that the latter inhibits renal excretion and so maintains therapeutic penicillin concentrations long enough to fight the gonorrhoeal infection.

The therapeutic regime introduced was as follows:

Probenecid, 1 g. (i.e. 4 tablets of $250 \mathrm{mg}$.) was administered by mouth. 15-30 min. later 5 million units sodium penicillin $\mathrm{G}$ in $8 \mathrm{ml}$. of a 0.5 per cent. lignocaine solution were injected intramuscularly. This combination gives an initial penicillinaemia of up to 200 units $/ \mathrm{ml}$; at the end of 8 hours the average blood level is 5 units $/ \mathrm{ml}$., and at the end of 24 hours 0.03-0.10 unit/ml. (Schmidt and Roholt, 1965).

Curtis and Wilkinson (1958) suggested a blood level above 1 unit $/ \mathrm{ml}$. maintained for 24 hours as the sine qua non for an ideal treatment of gonorrhoea. The resuits of our studies indicate that a penicillin level of this magnitude is not needed for longer than

\footnotetext{
$\star$ Received for publication January 7, 1969.
}

12 to 18 hours, provided that the initial level is very high. To avoid the emergence of gonococcal strains having an increased resistance to penicillin, rapid elimination of the penicillin is decisive.

This treatment was first tested in southern Greenland, but after 6 months' experience of its superiority over previous regimes, it was prescribed as routine treatment for gonorrhoea over the whole country of Greenland.

\section{Material}

The cases comprise all patients treated for uncomplicated gonorrhoeal urethritis and cervicitis diagnosed at the Gonococcal Laboratory in Julianehaab in southern Greenland from September 1964 to February 1968. If we include the 8 per cent. of patients who had to be treated with tetracycline because of previous signs of penicillin allergy, the series comprises 902 treatments (443 women and $458 \mathrm{men}$ ).

\section{Treatment and Follow-up}

The routine treatment was the combination of probenecid and sodium penicillin $G$ described above. To avoid painful reactions, the penicillin was dissolved in lignocaine 0.5 per cent. Patients who did not tolerate penicillin received a single oral dose of tetracycline, $1,500 \mathrm{mg}$. for men and $2,500 \mathrm{mg}$. for women.

In the early part of the study period we required negative results in three follow-up tests at intervals of one week before discharging the patients. As the efficacy of the treatment became apparent; the follow-up was restricted to two tests one week apart. Patients were instructed to abstain from sexual intercourse until the completion of the follow-up.

\section{The Gonococcus Laboratory}

This laboratory was established in 1964 at Julianehaab as a section of the Neisseria Department of the Statens Seruminstitut in Copenhagen (WHO Reference Laboratory). All specimens are cultured for the gonococcus; sensitivity to penicillin, streptomycin, and tetracycline is determined by the plate dilution method (Reyn, 1965). 


\section{Relapse or Re-infection}

If gonococci were demonstrated at a follow-up test, the following criteria were used to decide whether the patient had been re-infected or had relapsed. At least two of the criteria had to be fulfilled to diagnose reinfection.

(1) At least one negative culture after treatment.

(2) Admitted sexual intercourse after treatment with a person with suspected or proven gonorrhoea.

(3) Double deviation in the sensitivity patterns (penicillin, tetracycline, and streptomycin) found at the first test and at the follow-up test.

\section{Results}

Analysis of the results of the routine treatment with a combination of oral probenecid and intramuscular sodium penicillin $G$ involves 832 treatments (Table). The male/female ratio of approximately 1:1 (430 males and 402 females) is characteristic of the situation in Greenland. The 59 patients who did not attend for follow-up visits were people who were travelling along the coast, members of boat crews, or visitors. 93 per cent. of the treated patients attended for the first follow-up visit and 84 per cent. for the second, but many required several reminders.

Of those who attended for one or more follow-up tests, just over 97 per cent. of the males and almost 97 per cent. of the females could be considered as cured. In 23 cases gonococci were demonstrated at the first or second follow-up, and these were thoroughly assessed to decide between re-infection and relapse.

In twelve of them the first criterion of re-infection was fulfilled. Of the remaining eleven ( 7 women and 4 men) in whom gonococci were demonstrated at the first follow-up test, six had required several reminders. All 23 admitted further intercourse, most of them more than once. The sources of reinfection could be established with certainty or near certainty in nineteen of them and in this way the second criterion was fulfilled. In the remaining four cases the source of re-infection could not be established as one or more of the sexual contacts were not available. It should be pointed out that, in a small town like Julianehaab, of about 2,700 inhabitants, there are unusually favourable opportunities for contact tracing.

The third criterion, that of a double deviation in the sensitivity patterns, was fulfilled in seven of the 23 doubtful cases. In the remaining sixteen there was either no deviation at all or a change in sensitivity in only one of the three antibiotics.

Thus, in fifteen out of the 23 doubtful cases, at least two of the criteria were fulfilled, and these cases were regarded as definite re-infections. Accordingly the cumulative cure rate was 99 per cent. for males as well as females.

In the remaining eight cases relapse was possible, but here, too, various factors pointed to re-infection. All had had further intercourse and they had been treated for gonorrhoea an average of 5.6 times within the period of the study, while the remainder had had an average of 1.8 infections in the same period. Furthermore, only one of the eight was infected by a strain of gonococcus which showed reduced sensitivity to penicillin in vitro, and that to only a slight degree (mean inhibitory concentration $0.21 \mu \mathrm{g} . / \mathrm{ml}$.). Lastly, all eight were cured by a repeat of the routine therapy. In our view, therefore, the real cure rate with this treatment in Greenland may be regarded as 100 per cent.

All 23 "problem" cases received a repeat of the standard treatment. Two persons, both of whom had another re-infection after the second treatment, were discharged as cured after a third routine therapy.

69 patients ( 28 males and 41 females) who could not tolerate penicillin were treated by oral tetracycline. Among the 28 men there were two cases of relapse and among the women four relapses and one re-infection. This gives a cure rate with tetracycline of approximately 90 per cent. for both sexes.

\section{Treatment of Complicated Cases}

In the cases with very mild complications, such as incipient epididymitis, funiculitis, slight bartho-

TABLE

RESULTS OF ROUTINE TREATMENT OF GONORRHOEA WITH PROBENECID 1g, ORALIY AND ONE SINGLE INJECTION OF 5 MILLION UNITS SODIUM PENICILLIN G INTRAMUSCULARLY

\begin{tabular}{|c|c|c|c|c|c|c|}
\hline \multicolumn{2}{|l|}{ Sex } & \multirow{2}{*}{$\begin{array}{c}\begin{array}{c}\text { No. of } \\
\text { Patients }\end{array} \\
430\end{array}$} & $\begin{array}{l}\text { Gonococcus } \\
\text { Negative }\end{array}$ & Re-infected & \multirow{2}{*}{$\begin{array}{c}\begin{array}{c}\text { Possible } \\
\text { Relapses }\end{array} \\
4\end{array}$} & \multirow{2}{*}{$\frac{\begin{array}{c}\text { Not } \\
\text { Followed }\end{array}}{31}$} \\
\hline $\begin{array}{l}\text { Male } \\
\text { Cumulative Cure Rate }\end{array}$ & $\begin{array}{l}\text { No. } \\
\text { (Per cent.) }\end{array}$ & & $97 \cdot 2 \quad 388$ & $99 \cdot 0 \quad 7$ & & \\
\hline $\begin{array}{l}\text { Female } \\
\text { Cumulative Cure Rate }\end{array}$ & $\begin{array}{l}\text { No. } \\
\text { (Per cent.) }\end{array}$ & 402 & 362 & $98 \cdot 9$ & 4 & 28 \\
\hline $\begin{array}{l}\text { Total } \\
\text { Cumulative Cure Rate }\end{array}$ & $\begin{array}{l}\text { No. } \\
\text { (Per cent.) }\end{array}$ & 832 & $97 \cdot 0$ & $99 \cdot 0^{15}$ & 8 & 59 \\
\hline
\end{tabular}


linitis, or mild signs of salpingitis, the routine treatment was administered twice at an interval of 4 to 6 hours (Schmidt and Roholt, 1965). Patients with more advanced complications requiring rest in bed or admission to hospital were treated by the standard dose each morning and evening for 3 to 6 days.

\section{Sensitivity of Strains of Gonococci to Penicillin G}

This treatment with probenecid and sodium penicillin $G$ was introduced because of the high incidence of gonococcal strains having a reduced sensitivity to penicillin in vitro. Figs 1 and 2 illustrate the changes in the pattern of sensitivity to penicillin which occurred after the introduction of this regime, by showing the results in the first and second halves of the study period. During the first half (Fig. 1), 54 per cent. of the strains showed reduced sensitivity to penicillin in vitro. This accords with the finding of Lomholt and Berg (1966) that, in the summer of 1964, 47 per cent. of the strains in Julianehaab and surrounding districts showed reduced sensitivity to penicillin. During the second half of the study period (Fig. 2), only 19 per cent. of the strains showed a reduced sensitivity to penicillin in vitro, or about one-third of the previous incidence. The change in sensitivity had become manifest about one year after the introduction of the treatment, and the preponderance of penicillinsensitive strains has been increasing ever since. Similar changes have taken place in the sensitivities of the strains to streptomycin and tetracycline. This entire problem calls for further analysis.

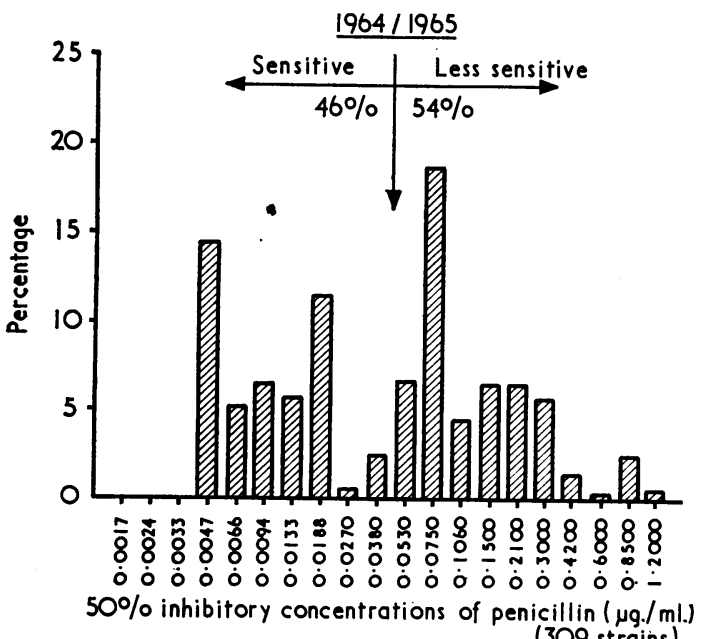

FIG. 1.-Sensitivity pattern of strains of $N$. gonorrhoeae to penicillin in vitro in first half of study period.

\section{Discussion}

The first $3 \frac{1}{2}$ years' experience of using a combination of $1 \mathrm{~g}$. probenecid and 5 mega units sodium penicillin $\mathrm{G}$ in the routine treatment of gonorrhoea has proved that this schedule of treatment has fully met our requirements. As a single treatment it has been simple to use, and the high cure rate obtained has eased the work of the paramedical personnel.

Probenecid has recently been used in several places as an adjuvant to penicillin in the treatment of gonorrhoea. Jensen, Kvorning, and Nørredam (1963) reported on its suitability in combination with 1 mega unit sodium penicillin $G$ in cases in which the sensitivity of the gonococcus to penicillin is reduced.

Evans (1966) mentioned the use of a combination of probenecid, procaine penicillin, and finally penicillinase to reduce the long "penicillin tail", a method said to comply fully with the requirements of Curtis and Wilkinson (1958). He stated, however, that the theoretical advantages were outweighed by the practical drawbacks, in that serious allergic reactions had been observed.

In 27 women infected with gonococci showing a reduced sensitivity to penicillin in vitro, Wren (1967) successfully used a treatment very like that employed in Greenland.

Holmes, Johnson, and Floyd (1967) used $1 \mathrm{~g}$. probenecid initially and injected 2.4 mega units procaine penicillin one hour later; in the next 18 hours they administered $0.5 \mathrm{~g}$. probenecid three times. The 58 patients so treated had no possibility of becoming re-infected, and relapse occurred in

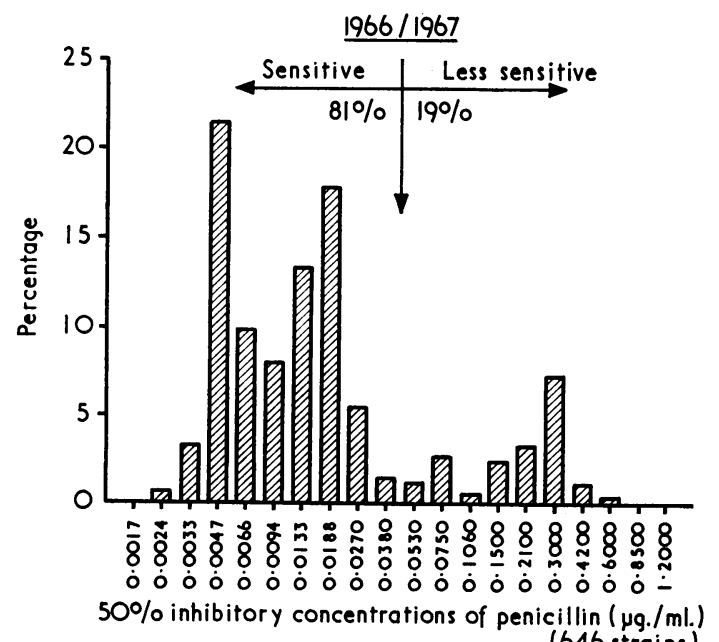

Frg. 2.-Sensitivity pattern of strains of $N$. gonorrhoeae to penicillin in vitro in second half of study period. 
one case. In a similar group these authors had first tested a treatment consisting of 2.4 mega units procaine penicillin, and had had a recurrence rate of 29.5 per cent. in 62 patients.

Of the types of treatment reported, however, only that of Jensen and others (1963) may be called a single treatment.

Using 5 mega units penicillin for the routine treatment of gonorrhoea may seem rather rigorous, but Lucas, Price, Thayer, and Schroeter (1967) reported a failure rate of 3.3 per cent. after 4.8 mega units procaine penicillin, half of which was in oily emulsion (PAM). Using only 2.4 mega units procaine penicillin the failure rate was more than double ( $8 \cdot 7$ per cent.).

When about 8,000 injections of 5 mega units sodium penicillin $\mathrm{G}$ had been administered as prophylactic group treatment in Greenland, mild signs of allergy occurred in only 0.6 per cent. and there were no serious allergic reactions.

To avoid "ping-pong" infections, Thayer, Perry, Magnuson, and Garson (1957), Guthe (1958), Durel and Roiron (1959), and WHO (1960) have stressed the desirability of bactericidal penicillin concentrations lasting for several days. If a single treatment was given, therefore, penicillins with a highlyprolonged effect were preferred, and these produced persistent subcurative serum penicillin levels for weeks. Chemoprophylaxis of this nature has previously been used in Greenland, and this seems to be the reason why Bøggild (1963) found a reduced sensitivity to penicillin in vitro of 86 per cent. of the gonococcal strains at Godthaab. Where similar chemoprophylaxis has been tried for syphilis (WHO, 1965; Thayer and Moore, 1964) similar changes in the sensitivity of gonococci have been observed.

The use of probenecid and sodium penicillin G in Greenland has had the opposite effect, as demonstrated above. Only 46 per cent. of gonococcal isolates had normal sensitivity to penicillin at the beginning of the study period, but by $1966 / 67$ the incidence was 81 per cent. This may be presumed to be a consequence of the new routine therapy and the intensification of prophylactic treatment of the population groups most exposed to risk.

\section{Summary}

The incidence of gonorrhoea in the population of Greenland is high, more than 100 in 1,000. A study in 1963 revealed that in certain areas 86 per cent. of gonococcal strains had a reduced sensitivity to penicillin in vitro and that treatment with penicillin in massive doses gave a failure rate of 27 per cent.
This paper reports the results of treatment with $1 \mathrm{~g}$. probenecid combined with 5 mega units sodium penicillin G in 832 uncomplicated cases of gonorrhoea. The cumulative cure rate was 99 per cent. for males and females. In the remaining 1 per cent. relapse could not be ruled out, but there was weighty evidence of re-infection in these cases also.

In the course of the study a considerable improvement was observed in the sensitivity of the gonococci to penicillin in vitro. When the combined treatment was first introduced, 56 per cent. of strains showed reduced sensitivity, but towards the end of the series the incidence was only 19 per cent. Such a marked reduction in the percentage of gonococcal strains with reduced sensitivity to penicillin has not previously been observed in the course of intensive penicillin therapy of gonorrhoea in major population groups.

\section{REFERENCES}

BøGGILD, J. (1965). Ugeskr. Laeg., 127, 476.

CURTIS, F. R., and WILKINSON, A. E. (1958). Brit. $\mathcal{F}$. vener. Dis., 34, 70

Durel, P., and RoIron V. (1959). Vie méd., 40, 35.

Evans, A. J. (1966). Brit. F. vener. Dis., 42, 251.

GuThE, T. (1958). Bull. Wld Hlth Org., 19, 405.

Holmes, K. K., Johnson, D. W., and Floyd, T. M. (1967). F. Amer. med. Ass., 202, 461.

Jensen, P. E., Kvorning, S. A., and Nørredam, K. (1963). Brit. F. vener. Dis., 29, 238.

LOMHOLt, G., and BerG, O. (1966). Ibid., 42, 1.

Lucas, J. B., Price, E. V., Thayer, J. D., and Schroeter, A. (1967). New Engl. F. Med., 276, 1454.

ReYN, A. (1965). Bull. Wld Hlth Org., 32, 449.

Schmidt, H., and RoHolt, K. (1965). Ugeskr. Laeg., $127,478$.

Thayer, J. D., and Moore, M. B. (1964). Med. Clin. N. Amer., 48, 755.

—, Perry, M. I., Magnuson, H. J., and Garson, W. (1957). Antibiot. and Chemother., 7, 311.

WHO (1960). Recommendations of European Symposium of IUVDT, Cracow, Poland, Oct. 1960. WHO/VDT $/ 265$.

(1965). Meeting of Neisseria Research Committee, 1st Report, Geneva. WHO/VDT/RES/Gon 1965. 8,65 .

Wren, B. G. (1967). Med. F. Aust., 1, 847.

Le traitement de la gonococcie par le probénécide combiné au sel sodique de pénicilline $\mathbf{G}$

\section{RÉSUMÉ}

L'incidence de la gonococcie au Groenland est élevée, plus de 100 par 1.000. Une étude en 1963 avait révélé que dans certaines régions 86 pour cent des souches de gonocoques avaient une sensibilité réduite à la pénicilline in vitro et que le traitement avec la pénicilline à doses massives donnait un taux d'échecs de 27 pour cent. 
Ce rapport donne les résultats du traitement avec $1 \mathrm{~g}$. de probénécide combiné à 5 méga-unités de sel sodique de pénicilline $G$ dans 832 cas de gonococcie sans complications. Le taux cumulatif de cure fut de 99 pour cent pour les hommes et les femmes. Parmi le un pour cent des cas qui restaient, une rechute ne pouvait être écartée, mais on trouvait aussi dans ces cas des signes évidents de réinfection.

Pendant cette étude, une amélioration considérable de la sensibilité des gonocoques à la pénicilline in vitro avait été observée. Juste au commencement du traitement combiné, 56 pour cent des souches montraient une sensibilité réduite, mais vers la fin de la série, l'incidence était seulement de 19 pour cent. Une si grande réduction dans le pourcentage des souches des gonocoques ayant une sensibilité réduite à la pénicilline n'avait pas été observée précédemment pendant un traitement intensif de la gonococcie par la pénicilline chez de larges gropnes de population. 